\title{
Utilization of Prognostic Indexes for Patients with Brain Metastases in Daily Radiotherapy Routine - is the Complexity and Intricacy Still an Issue?
}

\author{
Použití prognostických indexů pro pacienty s mozkovými \\ metastázami v denní radioterapeutické praxi - je jejich složitý \\ výpočet ještě stále problém?
}

\author{
Kazda T. ${ }^{1-3}$, Kuklova A. ${ }^{4}$, Pospisil P. ${ }^{1,2}$, Burkon P. ${ }^{1,2}$, Slavik M. ${ }^{1,2}$, Hynkova L. ${ }^{1,2}$, Prochazka T. ${ }^{5}$, Vrzal M. ${ }^{5}$, \\ Stavik M. ${ }^{5}$, Slampa P. ${ }^{1,2}$, Jancalek R. ${ }^{3,6,7 *}$
}

\begin{abstract}
1 Department of Radiation Oncology, Masaryk Memorial Cancer Institute, Brno, Czech Republic 2 Department of Radiation Oncology, Faculty of Medicine, Masaryk University, Brno, Czech Republic ${ }^{3}$ International Clinical Research Center, St. Anne's University Hospital Brno, Czech Republic ${ }^{4}$ Faculty of Medicine, Masaryk University, Brno, Czech Republic

${ }^{5}$ Department of Medical Physics, Masaryk Memorial Cancer Institute, Brno, Czech Republic ${ }^{6}$ Department of Neurosurgery, St. Anne's University Hospital Brno, Czech Republic ${ }^{7}$ Department of Neurosurgery, St. Anne's Hospital, Faculty of Medicine, Masaryk University, Brno, Czech Republic
\end{abstract}

\begin{abstract}
Summary
Background: Many prognostic indexes are available for patients with brain metastases in order to estimate remaining lifetime before selection of appropriate treatment including palliative radiotherapy. Their routine utilization is often deprecated for their complexity. We developed a practical tool based on widely available spreadsheet editors for facilitation of daily clinical use of selected indexes (RPA, GPA and WBRT-30) and evaluated its usage for retrospective single institutional survival analysis of patients irradiated for brain metastases. Patients and Methods: Spreadsheet platform was prepared and adjusted for automatic calculation of selected prognostic indexes after input of the relevant parameters. The consecutive series of newly diagnosed patients referred during 2011 to the palliative brain radiotherapy were analyzed, and real calculated survival parameters of individual subgroups of RPA, GPA and WBRT-30 were compared with estimated ones. Correlation of radiotherapy technique and estimated survival at the time of treatment indication was evaluated. Results: Total of 121 patients $(61 \%$ with multiple metastases) were irradiated with the majority undergoing whole brain radiotherapy. Median overall survival from the time of radiotherapy indication was 3.13 months. Non-balanced distribution into individual scoring systems subgroups was observed with $8(7 \%), 89(73 \%)$ and 24 (20\%) patients assigned to RPA 1, 2 and 3 subgroup, $3(3 \%), 9$ (7\%), 57 (47\%) and $52(43 \%)$ patients assigned to GPA 3.5-4, GPA 3.0, GPA 1.5-2.5 and GPA 0-1.0 subgroup and 10 (8\%), $88(73 \%)$ and 23 (19\%) patients assigned to WBRT-30 subgroup D, B and A. Entire differences in overall survival between subgroups are significant among all three scoring systems. Conclusion: Routine calculation of available prognostic indexes is useful in decision making regarding the best radiotherapy of brain metastases, and their calculation is greatly facilitated by properly prepared widely available spreadsheet tools.
\end{abstract}

Key words

prognosis - nomograms - cranial irradiation - RPA - GPA - WBRT-30
Supported by grants of the Czech Ministry of Health IGA NT/14600, NT/14120, by MH CZ DRO (MMCl, 00209805) and by European Regional Development Fund - Project FNUSA -ICRC (No. CZ.1.05/1.1.00/02.0123).

Tato práce byla podpořena grantem IGA MZ ČR NT/14600, NT/14120 a prostředky institucionální podpory výzkumné organizace MOÚ poskytnuté MZČR - DRO (MOÚ, 00209805). Podpořeno Evropským fondem pro regionálni rozvoj (ERDF), projektem FNUSA-ICRC (No. CZ.1.05/1.1.00/02.0123).

The authors declare they have no potential conflicts of interest concerning drugs, products, or services used in the study.

Autoři deklarují, že v souvislosti s předmětem studie nemaji žádné komerční zájmy.

The Editorial Board declares that the manuscript met the ICMJE recommendation for biomedical papers.

Redakční rada potvrzuje, že rukopis práce splnil ICMJE kritéria pro publikace zasilané do biomedicínských časopisů.

$\equiv$

Assoc. Prof. Radim Jancalek, MD, PhD International Clinical Research

Center

St. Anne's University Hospital Brno Pekarska 53

65691 Brno

Czech Republic

e-mail: radim.jancalek@fnusa.cz

Submitted/Obdrženo: 20. 5. 2015

Accepted/Príijato: 7. 6. 2015

http://dx.doi.org/10.14735/amko2015352 


\section{Souhrn}

Východiska: Existuje několik prognostických indexů pro pacienty s mozkovými metastázami, které mohou pomoci při rozhodování o nejlepší léčbě zahrnující mimo jiné i paliativní radioterapii. Jejich výpočet ale bývá poměrně složitý. Připravili jsme praktickou tabulku pro jejich jednoduchou kalkulaci, pomocí které jsme retrospektivně vyhodnotili vybrané prognostické indexy (RPA, GPA a WBRT-30) u pacientů podstupujících radioterapii na našem pracovišti. Soubor pacientů a metody: Byla vyhodnocena konsekutivní série pacientů ozařovaných v roce 2011 pro nově diagnostikované mozkové metastázy a jejich přežití bylo porovnáno s odhadovanou prognózou dle jednotlivých prognostických indexů a s použitou ozařovací technikou. Výsledky: Celkem bylo ozářeno 121 pacientů (61% s mnohočetnými metastázami), většina pacientů podstoupila celomozkové ozáření. Medián celkového přežití od data indikace radioterapie byl 3,13 měsíce. Rozložení pacientů do jednotlivých podskupin prognostických indexů bylo nerovnoměrné s 8 (7\%), 89 (73 \%) a 24 (20 \%) pacienty přiřazenými do RPA 1, 2 a 3 podskupiny, 3 (3\%), 9 (7 \%), $57(47 \%)$ a 52 (43\%) pacienty přiřazenými do GPA 3,5-4, GPA 3,0, GPA 1,5-2,5 a GPA 0-1,0 podskupiny a 10 (8 \%), 88 (73\%) a 23 (19\%) pacienty přiřazenými do WBRT-30 podskupiny $\mathrm{D}, \mathrm{B}$ a A. Celkové rozdíly v přežití jednotlivých podskupin byly statisticky signifikantní. Závěr: Odhad prognózy pacientů s mozkovými metastázami je důležitý a používání prognostických indexů je užitečné pro diagnosticko-terapeutickou rozvahu. Jejich výpočet je usnadněn vhodně prípravenými široce dostupnými tabulkovými editory.

\section{Klíčová slova}

prognóza - nomogram - ozařování mozku - RPA - GPA - WBRT-30

\section{Introduction}

The best radiotherapy (RT) practice concerning patients suffering from brain metastases (BM) is currently becoming more challenging, and optimal therapeutic approach remains controversial [1]. With increasing incidence of BM and overall survival (OS) time [2,3] and with wider availability of different RT systems, proper selection of patients is required to support adequate treatment recommendation in personalized cost-effective care [4,5]. Additionally, decision making between different RT approaches is intended to minimalize late adverse effects, especially in patients with better prognosis.

The portfolio of possible RT techniques is becoming more available, including classical whole brain radiotherapy (WBRT), stereotactic radiotherapy (SRT) or radiosurgery (SRS), simultaneous integrated BM boosting (WBRT + SIB) or currently investigated hippocampus sparing concept [6-9]. Indeed, more attention is paid to preserving cognitive function during palliative brain irradiation as highlighted also during the 2015 American Society of Clinical Oncology Annual Meeting at plenary session lecture about NCCTG N0574 trial a phase III randomized trial of WBRT in addition to SRS in patients with one to three brain metastases [10]. Results of this potentially practice changing trial reveal more cognitive declines after combination of WBRT with SRS, while no improvement in OS was described. Thus, identifi- cation of patients amenable for more local RT approach will be further emphasized.

Many prognostic scoring systems were developed in order to provide objective prognosis assessment and to define criteria for inclusion and stratification of patients with BM eligible for randomized clinical trials. Recursive partitioning analysis (RPA) was developed in 1997 by Gaspar et al. and is generally the best known scoring system [11]. RPA is based on prognostic factors identified in three seminal Radiation Therapy Oncology Group BM clinical trials. Adding number of metastases to the prognosis estimation, Sperduto et al. in 2008 [12] introduced Graded Prognostic Assessment (GPA). The latest system WBRT-30 was developed based solely on the data from patients treated by WBRT with dose 30 Gy delivered in 10 fractions $[13,14]$. It predicts 6-month-survival probability compared to median OS estimation provided by the other scoring systems.

However, using scoring systems in routine daily clinical practice may be depreciated for their complexity and intricacy; therefore, estimation based on the clinical experiences is often preferred. The goal of present study was to develop a practical tool based on widely available spreadsheet editors to facilitate daily clinical use of selected established prognostic scoring systems (RPA, GPA and WBRT-30) and to evaluate their usage for retrospective single institutional survival analysis of unselected patients irradiated for newly diagnosed BM.

\section{Patients and methods}

Patients and data selection

The consecutive series of newly diagnosed BM patients who were referred in 2011 to palliative brain RT in the Department of Radiation Oncology, Masaryk Memorial Cancer Institute, were enrolled into this study. Electronic medical records were reviewed for obtaining following preselected variables: age, sex, Karnofsky performance status (KPS) before brain irradiation, presence of extracranial metastases (yes/no), systemic treatment prior to WBRT (yes/no), status of primary tumor (controlled/uncontrolled), number of BM, cancer type (breast, melanoma, small cell lung cancer (SCLC), non-small cell lung cancer (NSCLC), gastrointestinal cancer (Gl), renal cell carcinoma (RCC), other), the date of RT indication, the date of the end of RT, the date of death or last follow-up visit, RT technique (whole brain radiotherapy (WBRT), stereotactic radiotherapy (SRT) or radiosurgery (SRS), WBRT with simultaneous integrated boost to metastasis (WBRT + SIB)) and the delivered dose.

\section{Prognostic scoring systems}

The prognostic systems were utilized for patients' stratification into individual groups. RPA divides patients into three subgroups based on the evaluation of KPS, age, primary tumor status and presence of extracranial metastases [11]. GPA considers four criteria (age, KPS, number of BM and primary tumor sta- 
tus) and divides patients into four subgroups [12]. WBRT-30 divides patients into four subgroups by assigned points for KPS, age, extracranial metastases and systemic treatment prior to WBRT status (Tab. 1): group A (6-9 points), group B (10-14 points), group $C$ (15-17 points) and group D (18-19 points) [13,14]. Above mentioned prognostic scoring indexes were calculated by interactive spreadsheet editor (Microsoft Office Excel 2007 (computer software), Redmond, Washington: Microsoft) designed for easy automatic enumeration of appropriate variables (age, KPS, etc.) and survival estimation (Fig. 1).

\section{Statistical analysis}

OS was estimated using Kaplan-Meier methodology as the time from the end of the RT course (a) and the date of the initial indication of RT till death or the last follow-up examination (b). Log-Rank test evaluated survival difference between subgroups defined by scoring systems. Particular scoring systems were compared with regard to positive predictive value (PPV) of correct estimation of survival longer than six months. Standard descriptive statistics were performed for categorical and continuous variables. Statistical analysis was conducted using JMP 10 Software (SAS Institute) and two-sided $a=0.05$ was considered statistically significant for all analyses.

\section{Results}

Patients' characteristics

Total of 121 patients ( $56 \%$ women, mean age 60.3 years, $28 \%$ with $\mathrm{KPS} \geq 90 \%$ ) met

Tab. 1. Scoring of different clinical variables and related points for calculation of WBRT-30 prognostic system [14].

\begin{tabular}{|c|c|c|c|c|}
\hline KPS & Age & $\begin{array}{l}\text { Extracranial } \\
\text { metastases }\end{array}$ & $\begin{array}{r}\text { Systemic } \\
\text { prior t }\end{array}$ & $\begin{array}{l}\text { atment } \\
\text { IBRT }\end{array}$ \\
\hline$<70 \quad 1$ & $<50 \quad 5$ & yes & yes & 3 \\
\hline$=70 \quad 4$ & $51-604$ & no & no & 2 \\
\hline$>706$ & $61-703$ & & & \\
\hline
\end{tabular}

KPS - Karnovsky performance status, WBRT - whole brain radiotherapy

the inclusion criteria. The most common primary diagnosis was NSCLC $(25 \%)$ and breast cancer (17\%). Twenty-five percent had solitary or single metastasis while $61 \%$ had $>3$ BM. The other patient's characteristics are summarized in Tab. 2 . Two out of 10 patients with WBRT + SIB did not finish prescribed course of radiation because of deteriorating overall clinical status and received only seven and nine fractions, resp.

\section{Prognostic scores and survival}

Median OS from the time of RT indication was 3.13 months $(95 \% \mathrm{Cl}$ 2.5-4.9 months) with a median of 2.4 months (95\% Cl 1.7-3.7 months) since the date of the end of RT. Corresponding 6-month-survival was $37 \%$ and $31 \%$, resp. According to RPA, 8 (7\%), $89(73 \%)$ and 24 (20\%) patients were assigned to group RPA 1, 2 and 3, resp. Results of other scoring system are listed in Tab. 3 along with achieved survival rates. No patient has met criteria for being assigned to WBRT-30 subgroup C (15-17 points). Entire differences in OS between subgroups are significant among all three scoring systems. On the other hand, for specific analysis of survival differences between two adjacent subgroups, significant differences are between RPA 2 and 3, GPA 1.5-2.5 and 0-1.0 and WBRT-30 A and B subgroups. Overall 12 patients were categorized to have favorable GPA score (>3.0), out of $75 \%$ of them $(9 / 12)$ had one BM. Corresponding Kaplan-Meier plots for OS calculated from the date of RT indication are in Fig. 2. PPV to correctly estimate survival longer than six months was $75 \%, 67 \%$ and $54 \%$ for RPA, GPA and WBRT-30, resp.

Calculated prognostic indexes for patients separated in accordance to RT techniques are summarized in Tab. 4. All four patients who received WBRT and had excellent RPA 1 score exhibited unfavorable GPA as well as unsatisfactory WBRT-30 score (survival 7.3, 6.0,

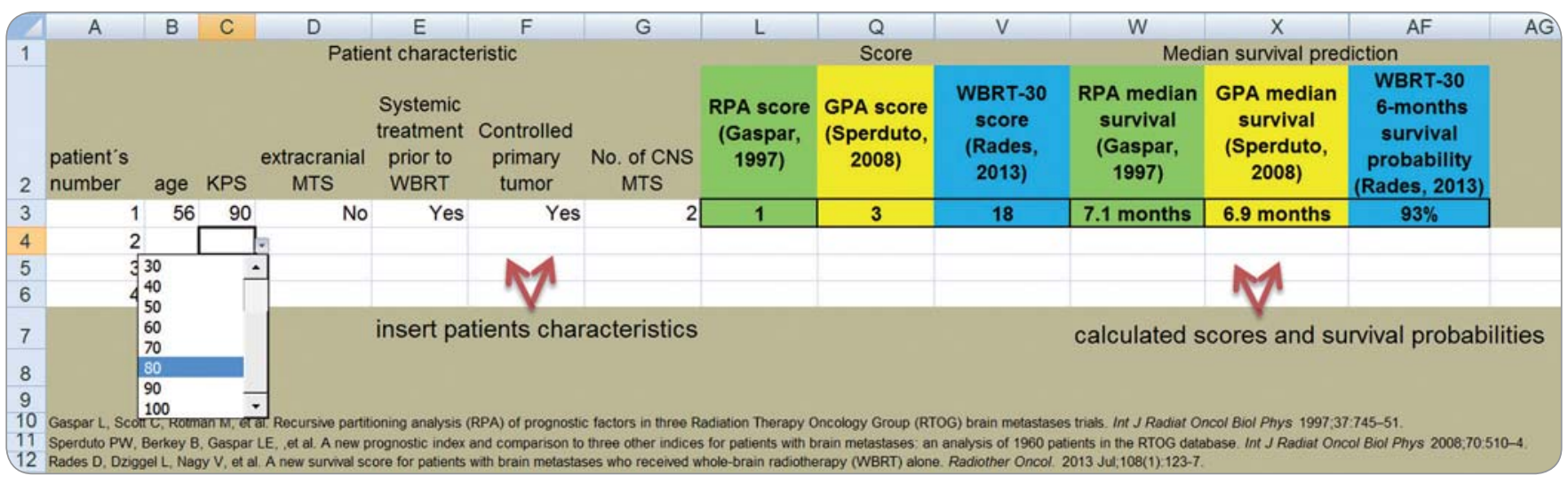

Fig. 1. Screenshot of prepared spreadsheet editor for recording of patient's information from electronic medical records and for automatic calculations of RPA, GPA and WBRT-30 scores. 


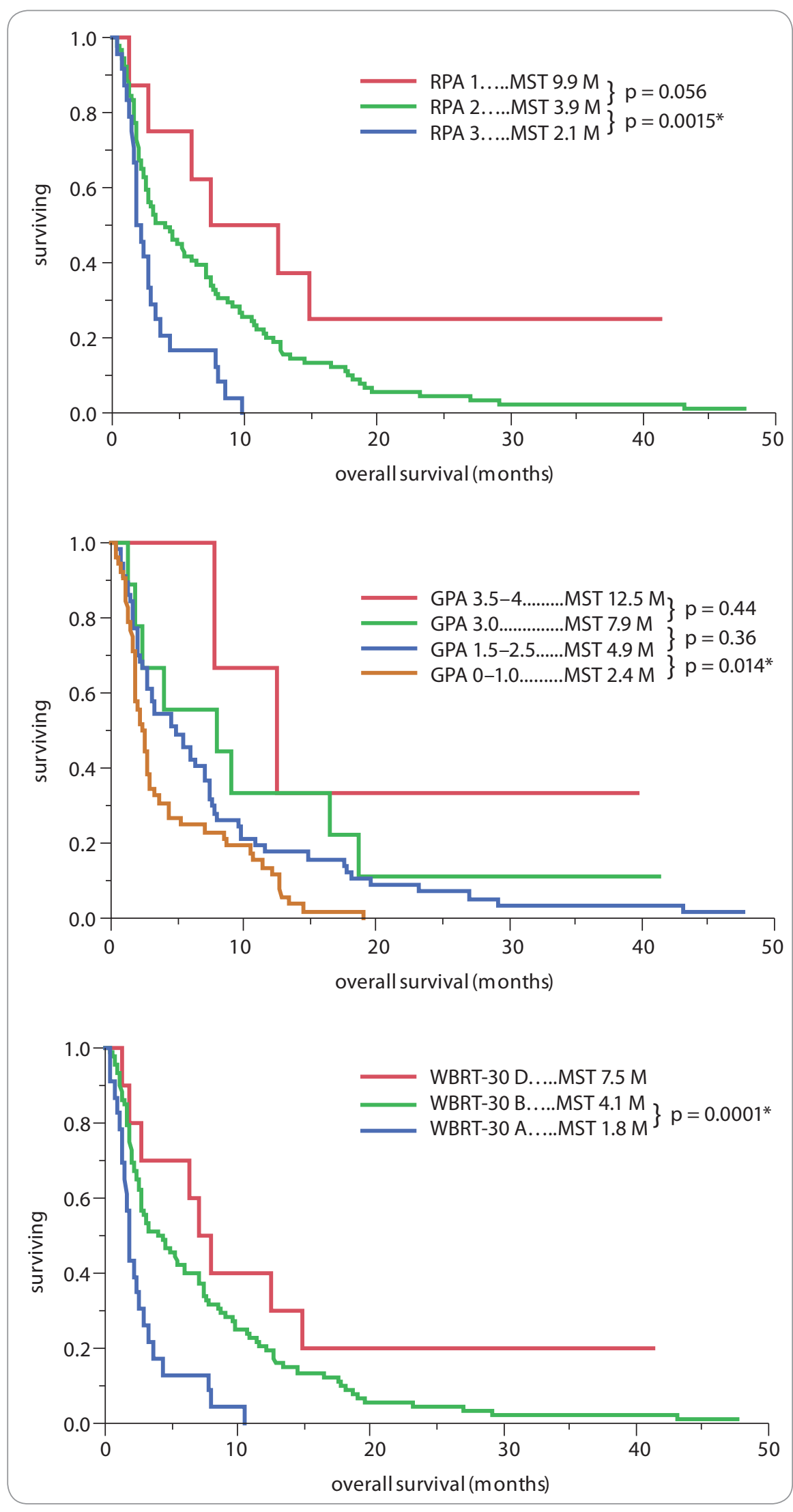

Fig. 2. Kaplan-Meier's survival estimation for RPA, GPA and WBRT-30 subgroups. No patient has met criteria for being assigned to WBRT-30 C subgroup.

MST - median survival time, M - months
39.7 and 41.3 months). One patient who had received WBRT + SIB with unfavorable RPA 3 also lacked in GPA and WB-30 score. However, his survival was 6.1 months from the end of RT.

\section{Discussion}

A total of 121 patients irradiated for BM during one year represent a significant cohort of patients which is without a doubt getting more heterogeneous. As such, heterogeneous treatment modalities are needed to address all patients' needs. The heterogeneity is also expressed by survival outcomes in our cohort when the median OS from the end of RT was only 2.4 months however, with 6-months actuarial survival rate of $31 \%$. Furthermore, increasing availability of MRI examination (sometimes also done as part of inclusion criteria for enrollment into some specific clinical trials) may reveal more patients with single asymptomatic BM. Thus, more aggressive treatment approach as surgery, SRT or simultaneous BM boosting may be suitable for increasing number of patients. Their identification may be inconsistent and problematic but could be facilitated by calculations of prognostic indexes for estimation of remaining lifetime. Developed prognostic indexes are designed with competing demands to be simple for usage in routine practice as well as accurate and as valid as possible. Therefore, all existing indexes have their pros and cons, and their refinement is an ongoing process with evaluation of new candidate parameters reflecting new investigations on biomarkers or radiomics signatures [15]. Moreover, many indexes are tailored for specific primary cancer diagnosis [16] or certain RT approach $[13,17]$. In the current systematic review of BM prognostic indexes published by Rodrigues et al. in 2012, a total of nine different prognostic indexes and eight validation studies were identified with a wide range of results in terms of PPV, negative predictive value, accuracy, likelihood ratio and other operating characteristics [18]. Altogether, selection of the best index for routine practice is problematic and significantly contributes to the common preference of survival estimation based on the treating physician's subjective evaluation. 
Multiple assessments of results obtained from more indexes may be the key for survival estimation in unselected patient cohort in routine daily practice. However, this approach requires even more substantial effort and complexity which is actually the major disadvantage of prognostic indexes. Based on the widely available spreadsheet platform, we developed a simple tool enabling automatic calculation of many indexes (Fig. 1). After filling the relevant parameters (age, KPS, etc.), predefined prognostic indexes are automatically calculated. Spreadsheet platform is especially useful for collecting information for subsequent research statistical analysis while smartphone- or web-based applications (in development) are more useful for routine usage in the outpatient department.

With our developed spreadsheet tool, we easily calculated RPA, GPA and WBRT-30 for a cohort of patients who underwent RT for newly diagnosed BM in 2011. Non-balanced distribution into individual subgroups corresponds with the most often discussed disadvantages of used indexes, with the small part of patients meeting criteria for inclusion into the good prognosis subgroup [18]. Only $7 \%$, 3\% and $8 \%$ were assigned to the best prognostic subgroup in RPA, GPA and WBRT-30 scoring system, resp. However, calculated survival rates in each subgroup are well distributed ranging from 2.1 to 9.9 , from 2.4 to 12.5 and from 1.8 to 7.5 months in RPA, GPA and WBRT-30, resp. Difference between adjacent subgroups (for example between RPA 1 and RPA 2 or between RPA 2 and RPA 3) is important for evaluation of impact of assigning to each subgroup. The most significant differences were observed using RPA system (relevant $p$-values are included in Fig. 2) favoring it over the others. In our cohort, RPA seems to be the best index for patient's stratification to identify patients who may benefit from more aggressive treatment. Two out of four patients with RPA 1 score who underwent WBRT exhibited extraordinary survival of 39.7 and 41.3 months and considering that they had one and two BM, more aggressive local treatment seems to be justified.
Tab. 2. Patients' clinical and treatment characteristics.

\begin{tabular}{lc}
\hline $\begin{array}{l}\text { Patients characteristics } \\
\text { age }\end{array}$ & $\mathbf{n = 1 2 1}$ \\
mean ( \pm SD) & $60.3( \pm 10.4)$ \\
sex & $53(44 \%)$ \\
male & $68(56 \%)$ \\
\hline female & \\
Karnofsky performance status & $34(28 \%)$ \\
\hline $90 \%$ & $34(28 \%)$ \\
\hline $80 \%$ & $29(24 \%)$ \\
\hline $70 \%$ & $16(13 \%)$ \\
$60 \%$ & $8(7 \%)$ \\
\hline $50 \%$ &
\end{tabular}

\section{primary cancer type}

non-small cell lung cancer $\quad 30(25 \%)$

small cell lung cancer $\quad 16(13 \%)$

breast $20(17 \%)$

melanoma $16(13 \%)$

gastrointestinal cancer $\quad 4(3 \%)$

renal cell carcinoma $3(2 \%)$

$\begin{array}{ll}\text { others } & 32(27 \%)\end{array}$

\section{disease status}

extracranial metastases $\quad 85(70 \%)$

systemic treatment prior WBRT 90 (74\%)

$\begin{array}{ll}\text { controlled primary tumor } & 55(46 \%)\end{array}$

\section{number of brain metastases}

$\begin{array}{cc}>3 & 74(61 \%) \\ 3 & 7(6 \%) \\ 2 & 10(8 \%) \\ 1 & 30(25 \%)\end{array}$

\section{RT technique}

WBRT $107(88.3 \%)$

WBRT + SIB

$10(8.2 \%)$

SRS

$3(2.5 \%)$

3D-CRT (5 fields)

$1(1)$

\section{RT dose}

$\begin{array}{lc}5 \times 4 \text { Gy } & 47(39 \%) \\ 10 \times 3 \text { Gy } & 34(28 \%) \\ 10 \times 3 \text { Gy + SIB (à } 4.0 \text { Gy and à } 4.3 \text { Gy) } & 3(2.5 \%) \text { and } 5(4 \%) \\ 1 \times 18 \text { Gy } & 1(0.8 \%) \\ 1 \times 20 \text { Gy } & 2(1.6 \%) \\ \text { single-fraction WBRT } & 10(8.3 \%) \\ \text { other } & 19(15.8 \%)\end{array}$

SD - standard deviation, WBRT - whole brain radiotherapy, RT - radiotherapy, SIB - simultaneous integrated boost, 3D-CRT - 3-dimensional conformal radiotherapy 
Tab. 3. Final OS in all subgroups calculated from both the time of the end of RT as well as from the time of RT indication.

$\mathrm{P}$-values describe significance of different survival between each adjacent subgroups. Median OS are in months.

\begin{tabular}{|c|c|c|c|c|c|c|}
\hline \multirow[b]{3}{*}{ RPA } & \multicolumn{3}{|c|}{ Median OS } & & & \multirow{2}{*}{$\begin{array}{l}\text { p (Log-Rank) } \\
\text { end of RT/indication }\end{array}$} \\
\hline & \multirow[t]{2}{*}{$n=121$} & \multirow[t]{2}{*}{ end of RT/indication } & \multicolumn{3}{|l|}{ RPA [11], GPA [12] } & \\
\hline & & & & & & \multirow{4}{*}{$\begin{array}{l}\text { 0.06/0.056 } \\
\text { 0.0021*/0.0015* }\end{array}$} \\
\hline 1 & $8(7 \%)$ & $8.4 / 9.9$ & 7.1 & - & - & \\
\hline 2 & $89(73 \%)$ & $2.9 / 3.9$ & 4.2 & - & - & \\
\hline 3 & $24(20 \%)$ & $1.4 / 2.1$ & 2.3 & - & - & \\
\hline \multicolumn{6}{|l|}{ GPA } & \multirow{5}{*}{$\begin{array}{l}\text { overall } 0.01 * / 0.0087^{*} \\
\begin{array}{l}\text { \} } 0.38 / 0.44 \\
\text { \} } 0.36 / 0.36 \\
\text { \} } 0.02 * / 0.014^{*}\end{array}\end{array}$} \\
\hline $3.5-4.0$ & $3(3 \%)$ & $11.5 / 12.5$ & 11.0 & - & - & \\
\hline 3.0 & $9(7 \%)$ & $6.4 / 7.9$ & 6.9 & - & - & \\
\hline $1.5-2.5$ & $57(47 \%)$ & $3.5 / 4.9$ & 3.8 & - & - & \\
\hline $0-1.0$ & $52(43 \%)$ & $1.7 / 2.4$ & 2.6 & - & - & \\
\hline
\end{tabular}

6-months survival

end of RT/indication WBRT-30 [13]

WBRT-30

\begin{tabular}{|l|c|c|}
\hline D: $19-18$ & $10(8 \%)$ & $5.9 / 7.5$ \\
\hline C: $17-15$ & 0 & - \\
\hline B: $14-10$ & $88(73 \%)$ & $3.0 / 4.1$ \\
\hline A: $9-6$ & $23(19 \%)$ & $1.2 / 1.8$ \\
\hline
\end{tabular}

RT - radiotherapy, OS - overall survival, RPA - Recursive partitioning analysis, GPA - Graded prognostic assessment, WBRT - whole brain radiotherapy

Tab. 4. Prognostic indexes for patients separated in accordance to RT techniques.

\begin{tabular}{|c|c|c|c|}
\hline & WBRT, n = 107 & WBRT + SIB, $n=10$ & SRS, $n=3$ \\
\hline RPA 1 & 4/107 (4\%) & $3 / 10(30 \%)$ & $1 / 3(33 \%)$ \\
\hline RPA 2 & $80 / 107$ (75\%) & $6 / 10(60 \%)$ & $2 / 3(67 \%)$ \\
\hline RPA 3 & 23/107 (21\%) & $1 / 10(10 \%)$ & - \\
\hline GPA 3.5-4.0 & 2/107 (2\%) & $1 / 10(10 \%)$ & - \\
\hline GPA 3.0 & 6/107 (5\%) & $2 / 10(20 \%)$ & $1 / 3(33 \%)$ \\
\hline GPA $1.5-2.5$ & 48/107 (45\%) & $6 / 10(60 \%)$ & $2 / 3(67 \%)$ \\
\hline GPA 0-1.0 & $51 / 107(48 \%)$ & $1 / 10(10 \%)$ & - \\
\hline WBRT-30 D & $5 / 107(5 \%)$ & $4 / 10$ (40\%) & $1 / 3(33 \%)$ \\
\hline WBRT-30 C & - & - & - \\
\hline WBRT-30 B & $80 / 107$ (75\%) & $5 / 10(50 \%)$ & $2 / 3(67 \%)$ \\
\hline WBRT-30 A & $22 / 107(20 \%)$ & $1 / 10(10 \%)$ & - \\
\hline
\end{tabular}

Our study has several limitations. The retrospective nature of the study is self-limiting, especially in validity of reported patients performance status and the status of primary tumor control. Control status records of primary disease (important part of RPA scoring system) lack standardization and are not generally evaluated by use of the same criteria. Another limitation of this study is small sample size of selected patients. Limited number of patients leads to low statistical power to identify significant differences between each prognostic subgroup within prognostic index. Low sample size also precludes diagnosis specific evaluation and more patients will be required to evaluate for example disease specific GPA, which is currently considered as the potentially most widely used index in the future $[16,19]$. However, to test our spreadsheet tool for simple indexes calculation, selection 
of patients within one year of clinical practice seems sufficient. Thus, sample extension is distinguished as a logical part of ongoing research.

In summary, our retrospective study proved feasibility of prognostic indexes evaluation for assessment of remaining lifetime in patients with brain metastases. Calculation is made much easier with prepared spreadsheet software which is now a standard part of computer equipment in all RT departments. Standard evaluation of prognostic indexes may increase probability that all suitable patients for more aggressive treatment will have an opportunity to get the best therapy. Future perspectives include incorporation of more iteration into our software tool for calculation of other prognostic indexes, enlarging sample size and identification of the best system for assessment of unselected patient's cohort.

\section{References}

1. Koay E, Sulman EP. Management of brain metastasis: past lessons, modern management, and future considerations. Curr Oncol Rep 2012; 14(1): 70-78. doi: 10.1007/s11912-011-0205-9.
2. Siegel R, Ma J, Zou Z et al. Cancer Statistics, 2014. CA Cancer J Clin 2014; 64(1): 9-29. doi: 10.3322/caac.21208. 3. Dusek L, Muzik J, Maluskova D et al. Cancer incidence and mortality in the Czech Republic. Klin Onkol 2014 27(6): 406-423. doi: 10.14735/amko2014406.

4. Kazda T, Pospisil P, Dolezelová $\mathrm{H}$ et al. Whole brain radiotherapy: consequences for personalized medicine. Rep Pract Oncol Radiother 2013; 18(3): 133-138. doi 10.1016/j.rpor.2013.03.002

5. Sedo J, Blaha M, PavlikT et al. Cost analysis of radiotherapy provided in inpatient setting - testing potential pre dictors for a new prospective payment system. Klin Onko 2014: 27(3): 192-202. doi: 10.14735/amko2014192.

6. Datta NR, Samiei M, Bodis S. Radiotherapy infrastructure and human resources in Europe - present status and its implications for 2020. Eur J Cancer 2014; 50(15): 2735-2743. doi: 10.1016/j.ejca.2014.06.012

7. Scoccianti S, Ricardi U. Treatment of brain metastases: review of phase III randomized controlled trials. Radiother Oncol 2012; 102(2): 168-179. doi: 10.1016/j.radonc.2011.08.041.

8. Gondi V, Pugh SL, Tome WA et al. Preservation of memory with conformal avoidance of the hippocampal neural stem-cell compartment during whole-brain radiotherapy for brain metastases (RTOG 0933): a phase I multi-institutional trial. J Clin Oncol 2014; 32(34): 3810-3816. doi: 10.1200/JCO.2014.57.2909

9. Kazda T, Jancalek R, Pospisil P et al. Why and how to spare the hippocampus during brain radiotherapy: the developing role of hippocampal avoidance in cranial radiotherapy. Radiat Oncol 2014; 9: 139. doi: 10.1186/1748-717X-9-139.

10. Brown P, Asher A, Ballman $K$ et al. NCCTG N0574 (Alliance): a phase III randomized trial of whole brain radiation therapy (WBRT) in addition to radiosurgery (SRS) in patients with 1 to 3 brain metastases. J Clin Oncol 2015: 33 (Suppl): abstr. LBA4.
11. Gaspar L, Scott C, Rotman M et al. Recursive partitioning analysis (RPA) of prognostic factors in three Radiation Therapy Oncology Group (RTOG) brain metastases trials. Int J Radiat Oncol Biol Phys 1997; 37(4): 745-751.

12. Sperduto PW, Berkey B, Gaspar LE et al. A new prognostic index and comparison to three other indices for patients with brain metastases: an analysis of 1,960 patients in the RTOG database. Int J Radiat Oncol Biol Phys 2008; 70(2): 510-514.

13. Rades $D$, Dziggel L, Nagy $V$ et al. A new survival score for patients with brain metastases who received whole-brain radiotherapy (WBRT) alone. Radiother Oncol 2013; 108(1): 123-127. doi: 10.1016/j.radonc.2013.06.009. 14. Rades D, Dziggel L, Nagy V et al. Erratum to "A new survival score for patients with brain metastases who received whole-brain radiotherapy (WBRT) alone" [Radiother Oncol 2013; 108(1): 123-127]. Radiother Oncol 2013; 109(2): 335. 15. Nieder C, Mehta MP. Prognostic indices for brain metastases - usefulness and challenges. Radiat Oncol 2009; 4: 10. doi: 10.1186/1748-717X-4-10.

16. Sperduto PW, Chao ST, Sneed PK et al. Diagnosis-specific prognostic factors, indexes, and treatment outcomes for patients with newly diagnosed brain metastases: a multi-institutional analysis of 4,259 patients. Int J Radiat Oncol Biol Phys 2010; 77(3): 655-661. doi: 10.1016/j. ijrobp.2009.08.025

17. Weltman E, Salvajoli JV, Brandt RA et al. Radiosurgery for brain metastases: a score index for predicting prognosis. Int J Radiat Oncol Biol Phys 2000; 46(5): 1155-1161.

18. Rodrigues G, Bauman G, Palma D et al. Systematic review of brain metastases prognostic indices. Pract Radiat Oncol 2013; 3(2): 101-106. doi: 10.1016/.jprro.2012.04.001. 19. Sperduto PW, Kased N, Roberge D et al. Summary report on the graded prognostic assessment: an accurate and facile diagnosis-specific tool to estimate survival for patients with brain metastases. J Clin Oncol 2012; 30(4): 419-425. doi: 10.1200/JCO.2011.38.0527. 